JPPUMA: Jurnal Ilmu Pemerintahan dan Sosial Politik UMA Uournal of Governance and Political Social UMA), 7 (1) (2019): 19-29

JPPUMA: Jurnal Ilmu Pemerintahan dan Sosial Politik UMA

(Uournal of Governance and Political Social UMA)

DOI: http://dx.doi.org/10.31289/ippuma.v7i1.1989

Available online http://ojs.uma.ac.id/index.php/jppuma

\title{
Politik Gender dan Otonomi Daerah: Upaya Pemenuhan Hak Perempuan Nelayan di Desa Sei Nagalawan
}

\section{Politics of Gender and Regional Autonomy: Efforts to Fulfill Fishermen's Women's Rights in Sei Nagalawan Village}

\author{
Fernanda Putra Adela1)*, Zakaria ${ }^{1)}$, Nurlela' ${ }^{2)}$, \& Adil Arifin1) \\ 1) Departemen Ilmu Politik, Fakultas Ilmu Sosial dan Ilmu Politik, \\ Universitas Sumatera Utara, Indonesia \\ 2) Departemen Ilmu Linguistik, Fakultas Ilmu Budaya, Universitas Sumatera Utara, Indonesia \\ Diterima: Oktober 2018; Disetujui: April 2019; Dipublish: Juni 2019
}

\begin{abstract}
Abstrak
Tulisan ini membahas persoalan yang dialami oleh istri-istri nelayan di Desa Sei Nagalawan yang mengalami bias sosial. Bias sosial dalam pengertian situasi paradox, dimana perempuan mengalami situasi paradoks yaitu ketika suami mereka pergi melaut untuk menangkap ikan. Secara otomatis tanggung jawab di keluarga dipegang oleh istri mereka. Tidak hanya itu, para istri nelayan tersebut juga setiap hari rutin menangkap ikan dipinggir pantai. Namun, sampai saat ini para perempuan tersebut tidak dianggap sebagai nelayan yang mengakibatkan mereka tidak bisa mendapatkan asuransi kesehatan dan akses untuk meminjam uang ke Bank. Tidak hanya peran perempuan nelayan dalam bidang sosial, ekonomi maupun lingkungan dalam aktivitas melawan kemiskinan. Penulis menggabungkan perspektif Marxis, Fenomenologis dan Etnometodologis dalam melawan fenomena diskriminasi dalam kedudukannya sebagai perempuan nelayan ditengah beban kerjanya yang bisa mencapai 18 jam perhari. Pada akhir tulisan ini penulis memaparkan bagaimana strategi perempuan nelayan di Desa Sei Nagalawan melawan kemiskinan dengan ikut aktif menangkap ikan dipinggir pantai, mengengembangkan ekowisata Kampung Nipah melaui Koperasi Serba Usaha Muara Maimbai, pengembangan UMKM dengan menjual makanan ringan berbahan baku mangrove (bakau) dan aktif melakukan aktivitas perjuangan demi memenuhi pengakuan perempuan sebagai nelayan. Sebab, menurut Undang-Undang Nomor 7 tahun 2016 tentang Perlindungan dan Pemberdayaan Nelayan,Pembudi Daya Ikan, dan Petambak Garam bahwa nelayan merupakan jenis pekerjaan yang berkaitan dengan menangkap ikan.
\end{abstract}

Kata Kunci: Perempuan Nelayan, Melawan Kemiskinan, Bias Sosial.

\begin{abstract}
This paper discusses the problems experienced by fishermen's wives in Sei Nagalawan Village who experience social bias. Social bias in the sense of a paradox situation, where women experience a paradoxical situation that is when their husbands go to sea to catch fish. Automatically the responsibilities in the family are held by their wives. Not only that, the fishermen's wives also regularly catch fish on the shore. However, until now these women were not considered fishermen which resulted in them not being able to get health insurance and access to borrow money from the Bank. Not only the role of fishing women in the social, economic and environmental fields in activities against poverty. The author combines the Marxist, Phenomenological and Ethnometodological perspectives in countering the phenomenon of discrimination in his position as a female fisherman amid the workload that can reach 18 hours per day. At the end of this paper the author describes how the strategies of fishing women in Sei Nagalawan Village fight poverty by actively catching fish on the shore, developing Kampung Nipah ecotourism through the Muara Maimbai Multipurpose Cooperative, developing MSMEs by selling mangrove (mangrove) raw materials and actively conducting struggle activities to fulfill the recognition of women as fishermen. Because, according to Law Number 7 of 2016 concerning Protection and Empowerment of Fishermen, Fish Cultivators and Salt Farmers, fishermen are a type of work related to fishing.
\end{abstract}

Keywords: Fishermen Women, Fight Poverty, Social Bias.

How to Cite: Adela, F.P. Zakaria, Nurlela, \& Arifin, A. (2019). Politik Gender dan Otonomi Daerah: Upaya Pemenuhan Hak Perempuan Nelayan di Desa Sei Nagalawan. JPPUMA: Jurnal Ilmu Pemerintahan dan Sosial Politik UMA (Journal of Governance and Political Social UMA), 7 (1): 19-29

*Corresponding author: ISSN 2549-1660 (Print)

E-mail: fpa.adela@gmail.com ISSN 2550-1305 (Online) 


\section{PENDAHULUAN}

Nelayan identik dengan kemiskinan. Hal ini terjadi karena nelayan terperangkap dalam eksklusi sosial (socialexclution) yang mengakibatkan nelayan termarjinalkan. Eksklusi sosial adalah sebuah kondisi dimana individu dan masyarakat terputus dari keterlibatan secara penuh dari aksebilitas masyarakat yang lebih luas. (Giddens, 2001).

Dimensi dari eksklusi sosial tersebut setidaknya memiliki tiga dimensi menyangkut ekonomi, sosial dan politik. Pada dimensi ekonomi memilih pekerjaan sebagai nelayan kerap menjadi alternatif terakhir karena terputusnya mereka dari pasar tenaga kerja. Modal (fiansialcapital) terbatas, mengakibatkan tidak ada pilihan lain kecuali mempekerjakan diri sendiri (self-employed) dengan kelembagaan produksi yang lebih besar yaitu sistem kapitalis. Ciri usahanya tidak bersifat bankable, berjalan tanpa asuransi dan tanpa manajemen yang baik. Akibatnya daya beli nelayan tersebut sangat rendah yang berdampak pada konsumsi, kondisi sandang dan pangan memprihatinkan.

Secara politik, pun demikian kebijakan pemerintah masih jauh dari keberpihakan pada nelayan. Hal ini disebabkan oleh absennya nelayan dalam proses regulasi dan kebijakan yang dilakukan oleh pemerintah pusat dan pemerintah daerah. Lebih lanjut, selama ini nelayan objek agenda politik 5 tahunan ketika pemilu berlangsung. (Bird: 2013)

Akibatnya bertahun-tahun lamanya nelayan hanya menjadi komoditi politik yang secara langsung tidak memiliki mandat langsung untuk menekan pemerintah. Secara sosial, jaringan nelayan terhadap dunia internasional juga terbatas. Hal ini terjadi karena tingkat pendidikan kawasan pesisir yang masih relatif rendah dan keterbatasan penguasaan terhadap bahasa asing dan teknologi menyebabkan secara nyata nelayan menjadi objek yang tidak dihitung. (Satria, 2010).
Pada sub-bagian yang lebih khusus, perempuan nelayan juga mengalami eksklusi sosial secara peran. Keberadaan dan aktivitas kerap diabaikan sebagai salah satu bagian yang penting dari pemangku kepentingan baik dari sisi regulasi dan kebijakan. Padahal perempuan nelayan juga berkontribusi dalam menghadapi jeratan eksklusi sosial yang lebih luas yang dampaknya terhadap keberlanjutan hidup mereka.

Kontribusi tersebut berupa peran penting perempuan nelayan dalam rantai kerja nelayan sehari-hari. Terutama untuk nelayan-nelayan yang menghasilkan ikan dalam skala kecil. Peran perempuan nelayan pasca melaut terkait pengolahan, pemasaran ikan dan olahan produk perikanan yang kerap tidak dihitung keberadannya, karena maskulinitas pekerjaan sebagai nelayan yang dipersepsikan hanya untuk laki-laki. Persepsi ini muncul didasari budaya sistem pembagian kerja yang menjangkut gender (Malau, 2014) (Munthe, 2018). Pemisahan pekerjaan antara laki-laki dan perempuan telah membentuk anggapan bahwa nelayan itu hanya laki-laki dan perempuan hanya sebagai pelengkap. (Lentisco dan Lee, 2015).

Lebih lanjut, jika riview kembali kemiskinan yang dialami oleh nelayan disamping permasalahan modal, keahliaan dan aksebilitas kebijakan. Permasalahan lainnya bisa disebabkan oleh konflik dengan kapal-kapal yang menggunakan pukat harimau (trawl) yang mengeruk habis ikan-ikan dilaut. Tidak sampai disitu penggunaan pukat harimau berpotensi merusak ekosistem laut yang dampaknya nelayan-nelayan kecil pada saat melaut pulang dengan tangan kosong.

Hal ini pula yang menjadi permasalahan nelayan Desa Sei Nagalawan, Kabupaten Serdang Bedagai, Sumatera Utara yang menjadi korban pembangunan yang sangat antroposentris. Pada awal 1980-an bersamaan dengan kampanye pemerintahan Soeharto tentang 
swasembada pangan, Indonesian juga sedang menggalakkan program pertambakan udang jenis windu secara nasional. Hutan mangrove yang luasnya 15 hektare di pesisir pantai timur Sumatera yang juga merupakan kawasan pesisir Desa Sei Nagalawan harus ditebangi demi menyukseskan program rezim Orde Baru tersebut.

Akibatnya hutan mangrove di kawasan sepanjang pesisir Desa Sei Nagalawan mengalami kerusakan dan kritis. Selain fungsi mangrove sebagai penahan gelombang air laut, pelindung dari abrasi dan penangkap sedimen lumpur laut. Mangrove juga menjadi tempat bertumbuh, berkembang dan berkembang biak ikan jenis udang dan kepiting. Dimana pada saat bertelur udang atau kepiting selalu menepi ke pesisir dan setelah anak-anak udang/kepiting beranjak remaja akan masuk ke tengah laut. Artinya peranan keberadaan mangrove terhadap hasil tangkapan nelayan-nelayan ketika melaut sangat sentral. Jika mangrove di kawasan pesisir sudah rusak maka bisa dipastikan udang tangkapan yang ada di laut juga akan sedikit.

Situasi ini tentu saja berdampak negatif terhadap hasil melaut nelayan Sei Nagalawan. Sebab, penghasilan nelayan tidak pernah cukup untuk kebutuhan sehari-hari mereka. Akibatnya, pilihan berhutang pada tauke dengan bunga pinjaman tinggi yang jumlahnya mencapai 25-30\% pun tidak bisa dihindari demi melangsungkan hidup keluarga. Hari demi hari hutang terus bertambah yang mengakibatkan keterikatan yang mengikat. Pada bagian ini terjadi relasi eksploitatif secara sosial-ekonomi antara tauke dan nelayan Desa Sei Nagalawan.

Permasalan lainnya adalah nelayannelayan Desa Sei Nagalawan harus berkonflik di laut dengan kapal-kapal penangkap ikan pukat harimau (trawl). Kompleksitas ini tentu memakan energi, istri-istri nelayan yang sejatinya membekali suami-suami mereka ke laut dengan makanan, ikut mempersiapkan jaring dan menyisihkan uang untuk membeli bensin untuk bahan bakar sampan suami mereka. Harus menerima kenyataan pulang dengan tangan kosong.

Sering sekali demi membantu kebutuhan keluarga akibat minimnya tangkapan suami mereka, para perempuan nelayan Desa Sei Nagalawan bekerja sebagai buruh pengupas udang di tempat tauke dengan bayaran Rp 4.000-5.000,00 per kilogram. Satu hari para istri-istri nelayan ini bisa mengupas 4-5 kilogram per hari. Artinya setiap hari para perempuan nelayan menghasilkan Rp.16.000-20.000,00 untuk membantu kebutuhan rumah tangga mereka. (Wawancara Ibu Suhartini)

Secara struktural peran perempuan nelayan ini kerap tidak dihitung karena kerap lupa dari kebijakan, baik kebijakan pemerintah pusat maupun pemerintah daerah yang mengakibatkan tidak ada perhatian terhadap perempuan nelayan dalam hal pembuatan regulasi perundangundangan. Oleh karena itu, penelitian berjudul "Politik Gender dan Otonomi Daerah: Upaya Pemenuhan Hak Perempuan Nelayan di Desa Sei Nagalawan'. Penting untuk dilakukan dalam rangka pemenuhan hak perempuan nelayan dalam kehidupannya. Terutama dalam konteks kebijakan dan otonomi daerah.

Tulisan ini refleksi kritik terhadap anggapan tidak adanya peran perempuan sebagai sebuah ide dan aktivitas nelayan. Secara struktural peran perempuan nelayan ini kerap tidak dihitung yang mengakibatkan tidak ada perhatian terhadap perempuan nelayan dalam hal pembuatan regulasi perundang-undangan. Perspektif tulisan ini berpijak pada pengalaman perempuan nelayan Desa Sei Nagalawan.

Pada dasarnya tulisan ingin menjawab pertanyaan-pertanyaan tentang posisi perempuan nelayan dengan 
pendekatan feminism dengan pertanyaanpertanyaan; Tulisan ini membahas persoalan yang dialami oleh istri-istri nelayan di Desa Sei Nagalawan yang mengalami bias sosial. Bias sosial dalam pengertian situasi paradox, dimana perempuan mengalami situasi paradoks yaitu ketika suami mereka pergi melaut untuk menangkap ikan. Secara otomatis tanggung jawab di keluarga dipegang oleh istri mereka. Tidak hanya itu, para istri nelayan tersebut juga setiap hari rutin menangkap ikan dipinggir pantai. Namun, sampai saat ini para perempuan tersebut tidak dianggap sebagai nelayan yang mengakibatkan mereka tidak bisa mendapatkan asuransi kesehatan dan akses untuk meminjam uang ke Bank. Tidak hanya peran perempuan nelayan dalam bidang sosial, ekonomi maupun lingkungan dalam aktivitas melawan kemiskinan. Penulis menggabungkan perspektif Marxis, Fenomenologis dan Etnometodologis dalam melawan fenomena diskriminasi dalam kedudukannya sebagai perempuan nelayan ditengah beban kerjanya yang bisa mencapai 18 jam perhari.

\section{METODE PENELITIAN}

Metode penelitian ini adalah kualitatif dengan paradigma kritikal. paradigma kritikal merupakan paradigma yang menganggap bahwa penelitian merupakan alat yang digunakan untuk mengekspos hubungan nyata (real relations) yang dibawah "permukaan" mengungkap mitos dan ilusi, dan menekankan pada usaha menghhilangkan kepercayaan da ide-ide yang salah, menekankan pada pembebasan dan pemberdayaan.

Metode kualitatif berkembang mengikuti suatu dalil sebagai proses yang tidak pernah berhenti (unfinished process). Ia berkembang dari proses pencarian dan penangkapan makna yang diberikan oleh suatu realitas dan fenomena sosial.

Metode yang dipilih dengan melakukan penelitian langsung ke Desa Sei Nagalawan dengan proses pengamatan langsung, wawancara, jurnal dan bukubuku. Penentuan informan sebagai sumber data dalam penelitian ini ditentukan pada subjek penelitian yang mempunyai pengetahuan dan pengelaman yang dibutuhkan peneliti sesuai dengan permasalahan penelitian, mampu mengemukakan pengetahuan dan pengalamannya dan mempunyai waktu untuk diwawancarai untuk keperluan penelitian.

Data dikumpulkan dimulai saat observasi awal, pra penelitian hingga wawacara langsung kepada informan di Desa Sei Nagalawan. Saat melakukan wawancara, peneliti menggunakan alat tulis dan catatan untuk mencatat hal-hal penting yang disampaikan oleh informan Penelitian ini menggunakan metode penelitian kualitatif yang akan menghasilkan data deskriptif berupa katakata tertulis secara lisan berdasarkan perilaku yang diamati. Pendekatan yang dilakukan mengarah pada pengalaman mengajar guru di sekolah yang diamati secara langsung oleh peneliti, lalu akan dideskripsikan secara tertulis. Dengan menggabungkan perspektif marxis, fenomenologis dan etnometodologis, Smith (1987) bergerak melampaui pemahaman yang diterima luas tentang pentingnya intersubjektivitas dalam penelitian kualitatif seperti etnografi, observasi partisipan dan wawancara. Dengan menyadari pengucilan dan pembungkaman suara kaum perempuan diberbagai bidang, tak terkecuali pula perempuan nelayan, yang terkonseptualisasi dunia sehari hari dengan problematis yakni secara terus menerus dibentuk, diciptakan dan dikenal oleh kaum perempuan didalamnya dan organisasinya yang dibentuk oleh faktorfaktor material eksternal atau relasi yang diperantarai secara tekstual. (Denzin dan Lincoln, 2009

Tahap analisis yang dilakukan adalah membuat daftar pertanyaan untuk wawancara, pengumpulan data dan analisis data yang dilakukan sendiri oleh peneliti sehingga kemudian didapat 
kedalaman informasi yang diberikan informan peneltian.

\section{HASIL DAN PEMBAHASAN}

Perempuan nelayan juga mengalami eksklusisosial secara peran. Keberadaan dan aktivitas kerap diabaikan sebagai salah satu bagian yang penting dari pemangku kepentingan baik dari sisi regulasi dan kebijakan. Padahal perempuan nelayan juga berkontribusi dalam menghadapi jeratan eksklusi sosial yang lebih luas yang dampaknya terhadap keberlanjutan hidup mereka. Kontribusi tersebut berupa peran penting perempuan nelayan dalam rantai kerja nelayan seharihari. Terutama untuk nelayan-nelayan yang menghasilkan ikan dalam skala kecil.

Peran perempuan nelayan pasca melaut terkait pengolahan, pemasaran ikan dan olahan produk perikanan yang kerap tidak dihitung keberadannya, karena maskulinitas pekerjaan sebagai nelayan yang dipersepsikan hanya untuk laki-laki. Persepsi ini muncul didasari budaya sistem pembagian kerja yang menyangkut gender.

Hal ini pula yang menjadi permasalahan nelayan Desa Sei Nagalawan, Kabupaten Serdang Bedagai, Sumatera Utara yang menjadi korban pembangunan yang sangat antroposentris. Pada awal 1980-an bersamaan dengan kampanye pemerintahan Soeharto tentang swasembada pangan, Indonesian juga sedang menggalakkan program pertambakan udang jenis windu secara nasional. Hutan mangrove yang luasnya 15 hektare di pesisir pantai timur Sumatera yang juga merupakan kawasan pesisir Desa Sei Nagalawan harus ditebangi demi menyukseskan program rezim Orde Baru tersebut.

Akibatnya hutan mangrove di kawasan sepanjang pesisir Desa Sei Nagalawan mengalami kerusakan dan kritis. Selain fungsi mangrove sebagai penahan gelombang air laut, pelindung dari abrasi dan penangkap sedimen lumpur laut. Mangrove juga menjadi tempat bertumbuh, berkembang dan berkembang biak ikan jenis udang dan kepiting. Dimana pada saat bertelur udang atau kepiting selalu menepi ke pesisir dan setelah anak-anak udang/kepiting beranjak remaja akan masuk ke tengah laut. Artinya peranan keberadaan mangrove terhadap hasil tangkapan nelayan-nelayan ketika melaut sangat sentral. Jika mangrove di kawasan pesisir sudah rusak maka bisa dipastikan udang tangkapan yang ada di laut juga akan sedikit.

\section{Perempuan Nelayan Desa Sei Nagalawan}

Pada saat tim peneliti melakukan riset di lapangan. Saat itu hampir tidak ada laki-laki di Kawasan Ekowisata Kampung Nipah tersebut kecuali yang ditempatkan menjaga lokasi parkir. Praktis di kawasan tersebut hampir semuanya perempuan, sekitar 15 orang perempuan menyambut kami di Kampung Nipah. Salah satunya adalah Jumiati (37 tahun) yang 5 tahun lalu. Satu dari tujuh perempuan nelayan yang meraih penghargaan pejuang pangan dari Lembaga Sosial masyarakat (Nongovernmental organization) Inggris Oxfam sebagai perempuan nelayan pejuang pangan. Lebih lanjut, terpilihnya Jumiati didasarkan kontribusinya memberdayakan segala sumber daya untuk menghidupkan pangan masyarakat Desa Sei Nagalawan.

Jumiati menceritakan pada sekitaran akhir tahun 1990-an sampai tahun 2004 posisi Perempuan Nelayan Desa Sei Nagalawan yang kerap tidak diperhitungkan dalam rantai kerja. Padahal secara nyata, beban yang dihadapi oleh perempuan nelayan yang membuat bekerja setidaknya 18 jam dalam satu hari. Bagaimana tidak, selepas menjalankan sholat subuh, para perempuan nelayan akan langsung disibukkan dengan berbagai urusan menyediakan bekal melaut suami, menyiapkan bensin untuk bahan bakar 
sampan hingga menyiapkan jala suamisuami ketika melaut. Setelahnya para perempuan nelayan mulai melakukan pekerjaan rumah tangga. Sebahagian lagi bekerja sebagai pengupas udang hasil tangkapan di tempat penjualan yang lokasinya tidak jauh dari rumah mereka.

Tidak hanya itu, Jumiati melanjutkan peran perempuan nelayan penting dalam kehidupan ekonomi Nelayan Desa Sei Nagalwan juga ikut dalam kegiatan transaksi jual-beli dipasar dari hasil tangkapan suami-suami mereka. Apalagi rezeki nelayan itu tergantung cuaca, jika cuaca buruk karena ombang sangat besar dan angin kencang para suami-suami tidak melaut. Artinya dalam hitungan satu bulan (30 hari) nelayan Desa Sei Nagalawan hanya melaut 20 hari dengan hitungan 10 hari melaut 5 hari istirahat, 10 hari kerja 5 hari istirahat.

Jumiati melanjutkan "Itu juga hasil tangkapan tidak menentu tergantung cuaca, hasilnya bisa banyak juga bisa sedikit pula tidak mendapatkan apa-apa sama sekali. Jadi hasil tangkapannya kayak rezeki-rezeki harimau" (Bahasa pesisir yang menjelaskan tentang hasil tangkapan fluktuatif nelayan bisa besar, kecil atau tidak mendapatkan apa-apa sama sekali.)

Permasalahan lain para istri-istri nelayan Desa Sei Nagalawan tersebut, selepas melaut suami-suami mereka tidak langsung pulang ke rumah. Beberapa nelayan terlihat menghabiskan waktunya di warung-warung kedai kopi, kedai tuak hingga menghabiskan waktu semalam suntuk untuk berjudi dengan para nelayan lainnya. Uang hasil tangkapan ikan kerap dihabiskan untuk foya-foya dan minumminuman keras. Pada kondisi ini, sifat buruk tanpa pernah memikirkan masa depan keluarga menjadi kekhawatiran para istri-istri nelayan yang kurang memperhatikan kesejahteraan keluarga.

Akibatnya peran-peran sosial lakilaki seperti arisan, menghadiri acara pernikahan hingga hingga melayat orang meninggal kerap dihadiri istri-istri tanpa didampingi oleh suami mereka. Berbagai alasan muncul ketika peran laki-laki secara otomatis tergantikan oleh istri-istri nelayan. Seperti; Bertepatan dengan jam melaut, suami-suaminya sedang kecapean hingga alasan berkumpul dengan sesama nelayan lain untuk menyegarkan pikiran.

Pembangunan modal sosial pun secara otomatis bergeser dari peran lakilaki ke peran perempuan nelayan. Pada kondisi ini, fenomena peran sosial yang ada di Desa Sei Nagalawan membantah apa yang ditulis oleh Rogers yang mengemukakan proses domestik perempuan. Kehidupan perempuan terpusat pada rumah tangga dan kurang atau terlibat dalam segala pekerjaan di luar rumah, laki-laki bekerja di luar rumah dan menjamin kebutuhan perempuan. Pembagian kerja yang menekankan lakilaki sebagai kepala keluarga dan pencari nafkah utama diterima dalam masyarakat. (Rogers, 1980)

Lebih lanjut, pada kondisi yang tidak sadar karena budaya patrilinier di Desa Nagalawan yang didiami oleh tida suku seperti Suku Jawa, Suku Melayu dan Suku Banjar. Pembagian kerja terkait peran sosial tidak pernah di permasalahkan. Namun, permasalahan muncul ketika posisi antara laki-laki dan perempuan terkait hubungan kerja dan bagaimana memberikan nilai terhadap prestasi masing-masing. Nurhadi (1984) menyatakan peran sosial terkait aktivitas laki-laki dan perempuan secara seksual tidak menjadi sesuatu yang keliru, akan tetapi penilaian berat sebelah yang dipertanyakan keabsahannya yang diperkirakan semakin maju masyrakat semakin menuju ke pembagian kerja anggota masyarakat atau menuju ke sosialisasi sehingga terjadi ikatan karena adanya ketergantungan (Suardiman, 2001).

Pada awal tahun 2000-an, sebenarnya nelayan laki-laki mendirikan kelompok nelayan Desa Sei Nagalawan bernama Kayuh Baimbai. Kelompok ini 
diinisiasi sebagai wadah para nelayannelayan Desa Sei Nagalawan untuk memecahkan permasalahan terkait hutang, kemiskinan, dan Trawl. Namun, seiring berjalannya waktu kelompok Kayuh Baimbai tidak berjalan eksis akibat beberapa faktor terkait pemenuhan terhadap kebutuhan rumah tangga masing-masing keluarga. Apalagi para nelayan Desa Sei Nagalawan harus berhadapan dengan Trawldi laut yang mengakibatkan komunitas Kayuh Baimbai tidak fokus menjalankan rencana kerjanya akibat tuntutan cicilan utang pada tauke, pembiayaan sekolah anak-anak mereka dan kekhawatiran menghadapi hari lebaran agar tidak kesusahan. Agar anakanak mereka bisa membeli baju baru ketika lebaran, tidak hanya itu makan ketupat, lontong dan opor ayam dihari lebaran menjadi mimpi nelayan-nelayan Desa Sei Nagalawan.

Berselang 4 tahun, pada tahun 2004, Jumiati bersama istri-istri nelayan Desa Sei Nagalawan seperti Syarifah Aripah (41 tahun), Niah (45 tahun), Saniah (39 tahun) dan istri-isti nelayan lainnya mulai mendirikan kelompok Perempuan Nelayan bernama Muara Tanjung. Kelompok ini pada awalnya hanyalah arisan mingguan dengan sistem bergilir untuk sekedar peralatan dapur seperti kuali, cangkir, gelas atau piring. Sebab, dengan transaksi pembayaran Rp.150.000-200.000 untuk barang-barang tersebut sangat terasa berat terhadap ekonomi keluarga. Untuk itu, para isti-istri nelayan Desa Sei Nagalawan kerap mendapatkan perabotan rumah tangga dengan sistem bergilir dengan cicilan Rp.5.000,00 perminggu. Perkumpulan ini mereka lakukan ketika suami-suami mereka pergi melaut atau setelah waktu luang para perempuan nelayan tersebut selepas bekerja sebagai buruh lepas pengupas udang di rumah produksi para tauke/tengkulak.

Pada kondisi ini, vakumnya kelompok nelayan Kayuh Baimbai menyadarkan perempuan nelayan Desa Sei Nagalawan untuk melakukan aktivitas sosial yang bermanfaat. Perempuan nelayan secara sadar merasa harus melakukan perubahan dalam cara-cara bersikap, bertindak dan berpikir agar memainkan peranannya sesuai dengan kesadarannya. Meski harus diakui, hal ini tidak pernah dihitung sebagai sebuah nilai yang kontribusinya yang besar dalam keluarga karena hanya sebatas menghasilkan peralatan rumah tangga. Aktivitas perempuan nelayan merupakan hal yang penting dalam mengurangi beban keluarga. Meski keadaan ini menjadi hal yang sulit karena anggapan yang berkembang dalam maskulinitas nelayan bahwa perempuan tergantung pada laki-laki. Ketergantungan perempuan yang berawal dari ketergantungan makanan pada laki-laki berkembang pada aspek kehidupan dan sudah berada dalam kemapanan struktur, adat istiadat maupun tradisi. Pada kedaan tertentu perempuan nelayan menjalankan strategi tertetu untuk dapat bertahan hidup. (Suardiman, 2001).

Perananan perempuan nelayan Desa Sei Nagalawan tentu menjadi bias jika hanya dilihat dari aspek struktur dan adat istiadat yang patriliniear. Namun, secara empirik peran-peran tersebut tanpa disadari mampu dilawan oleh perempuan nelayan Sei Nagalawan dengan motivasi yang sederhana. Lebih lanjut, terkait perempuan nelayan yang bekerja sebagai buruh harian lepas pengupas udang menyangkut kesadaran akan pemenuhan kebutuhan hidup. Seperti yang dikemukakan oleh Ware (1981) bahwa "Women work because they choose to and not because they have to" (Ware, 1981)

\section{Tidak Sekadar Pendamping Nelayan}

Pada pembahasan diatas telah kami paparkan tentang bagaimana perempuan nelayan Desa Sei Nagalawan melawan bias sosial dalam kehidupan sebagai masyrakat pesisir di tengah maskulinitas pekerjaan sebagai nelayan. Pada bahasan selanjutnya tulisan ini akan memaparkan bagaimana 
posisi perempuan nelayan melawan kemiskinan di hadapan negara. Satu tahun berjalan arisan kelompok perempuan nelayan Muara Tanjung. Pada tahun 2005, para perempuan nelayan yang dimotori oleh Jumiati mulai melakukan reboisasi terhadap mangrove di kawasan pesisir Desa Sei Nagalawan.

Pada saat itu, Jumiati mengajak para perempuan nelayan penyadaran akan pentingnya kelestarian pesisir. Selain efeknya sebagai tempat tumbuh dan berkembang biak udang dan kepiting, juga menjadi salah satu penahan abrasi air laut yang bisa merambah pesisir 200-300 meter dari bibir pantai. Apalagi pada saat itu, baru saja terjadi Tsunami di Aceh tahun 2004 dan gempa di kepulauan Nias, Sumatera Utara tahun 2005. Sosialisasi ini dilakukan secara terus menerus dengan narasi cerita masa lalu. Desa Sei Nagalawan adalah wilayah yang asri dengan tumbuhan mangrove.

Apa yang dialami oleh Jumiati di Desa Sei Nagalawan pernah dituliskan oleh Vance (1992) dalam kumpulan tulisan yang dibukukan Greta Gaard berjudul "Ecofeminism Women, Animals, Nature". Lebih lanjut, Vance menulis paper yang berjudul "Ecofeminisme and the politic of reality" menjelaskan; bagaimana dirinya mengenang masa-masa kecil dengan hutan yang lebat dan lingkungan yang bersih. Namun harus kehilangan semuanya karena keputusan-keputusan politik yang sangat patrialki.

Dirinya bahkan sulit untuk kembali ke masa dimana kelestarian alam itu menjadi bagian yang tidak terpisahkan dari kenangan yang dimilikinya (Gaard, 1992). Lebih lanjut, Shiva (1993) mengatakan ketika hutan hancur, sungai mengalami kerusakan, saat keanekaragaman hayati dicuri akibat kegiatan ekonomi, ini adalah pertanyaan untuk bertahan hidup bagi orang-orang ini. Jadi gerakan lingkungan kita adalah gerakan tentang keadilan.

\section{Perempuan Nelayan dan Kebijakan}

Perempuan merupakan aktor yang harus berperan dalam penyelamatannya. Artinya kegiatan konservasi yang dilakukan oleh Jumiati dan perempuan nelayan lainnya menjadi titik penting mereka sebagai aktor penyelamatan Desa Sei Nagalawan. Tidak hanya menyangkut masalah kemiskinan tetapi juga tentang bagaimana tanggung jawab mereka terhadap keberlangsungan anak-cucu mereka kelak di Desa Sei Nagalawan.

Menurut Sutrisno (42 tahun), presidium Koalisi Rakyat Untuk Keadilan Perikanan (KIARA) yang juga merupakan suami dari Jumati mengatakan; "Peran perempuan nelayan terutama kelompok Muara Tanjung sangat signifikan dalam membantu kami (nelayan). Terutama ketika sedang melaut yang pastinya menangkap ikan, gerakan penanaman bakau agar lestari menjadi titik penting dalam kesejahteraan Nelayan Desa Sei Nagalawan".

Hanya saja, lanjut Sutrisno perempuan nelayan belum diakui oleh negera meskipun secara tersirat UndangUndang Republik Indonesia Nomor 7 Tahun2016 Tentang Perlindungan Dan Pemberdayaan Nelayan, Pembudi Daya Ikan, dan Petambak Garam sudah membahas tentang perempuan nelayan. Perempuan nelayan masih absen dalam setiap kebijakan terkait nelayan misalnya terkait pinjaman modal ke Bank, terkait pelatihan-pelatihan terkait perikanan yang dilakukan oleh pemerintah pusat/pemerintah daerah dan asuransi kepada perempuan nelayan seacar khusus belum diberikan.

Sutrisno melanjutkan "Padahal yang kita inginkan selama ini, terlepas dari posisi gender antara laki-laki dan perempuan secara bilogis masih bias dalam pengertian nelayan. Namun, mereka (perempuan nelayan) kini tidak boleh dipandang hanya sebagai pendamping suami saja".

Selanjutnya pada tahun 2009, ketika mangrove di Desa Sei Nagalawan sudah 
mulai tumbuh. Kelompok perempuan nelayan Muara Tanjung mulai mengembangkan usaha penjualan makanan/minuman berbasis bahan baku mangrove. Lebih lanjut, perempuan nelayan Muara Tanjung mulai usaha penjualan produk makanan ringan tradisional tanpa barang pengawet berbahan baku mangrove (bakau). Seperti; keripik Nipah seharga Rp.10.000,00 perbungkus, teh jeruju seharga Rp.10.000,00 perbotol, dodol seharga Rp.15.000, 00 per bungkus dan sirup seharga Rp.20.000,0 perbungkus.

Keunikan objek tulisan ini terletak pada bagaimana perempuan nelayan Desa Sei Nagalawan menggunakan basis komunitas mengembangkan secara swadaya (mandiri). Pengembangannya baik itu untuk konservasi dan usaha dilakukan tanpa bantuan Pemerintah Pusat, pemerintah Provinsi Sumatera Utara maupun Pemerintah kabupaten Serdang Bedagai. Artinya dengan konsep seperti ini, secara tidak langsung sebenarnya perempuan nelayan Desa Sei Nagalawan memiliki akses terhadap mangrove. Tapi dengan catatan, bahwa akses itu diberikan atas persetujuan nelayan laki-laki.

Perempuan nelayan sebenarnya tidak hanya dilihat secara fungsi sebagai sebuah pendamping saja. Raymond Bryant (1997) dalam bukunya yang berjudul "Third World Political Ecology" menjelaskan tentang fenomena kerusakan lingkungan yang terjadi di negara-negara dunia ketiga termasuk Indonesia bersumber pada kegiatan politik dan kebutuhan ekonomi.

Perubahan lingkungan seperti yang terjadi di desa Sei Nagalawan yang pada awalnya adalah kawasan mangrove yang luas dan lestari kemudian ditebangi untuk kepentingan ekonomi negara melalui pembangunan tambak untuk usaha udang windu. Setelahnya, masa subur pertambakan hanya 10-15 tahun lalu ditinggalkan negara begitu saja tentu menyisakan permasalahan yang sifatnya ekologis yang berpotensi melahirkan bencana dan kemiskinan. Lingkungan (pantai) dipolitisasi hanya untuk mengakses sumber-sumber ekonomi, kemudian yang menjadi korban utama adalah perempuan dan anak.

Namun, lebih dari sekadar pendamping nelayan. Para perempuan nelayan bahkan mampu membantah tulisan Raymond Bryant yang membagi peran-peran stakeholders (pemangku kepentingan) dalam rangka pengelolaan lingkungan atau pemanfaatan laut. Seperti; negara (pemerintah pusat/daerah), pengusaha, Lembaga Sosial Masyarakat (LSM) dan masyarakat sebagai aktor utama dalam setiap pengelolaan lingkungan. Di akhir pembahasan Bryant menyimpulkan dalam tujuan pengelolaan lingkungan lestari dibutuhkan kolaborasi aktor-aktor tersebut untuk mengakomodasi setiap kepentingan yang ada.

Menurut Bryant yang mengatakan Negara melalui pemerintah pusat memiliki kepentingan untuk kelestarian lingkungan demi eksistensi rutinias konferensi di tataran global, pemerintah daerah memiliki kepentingan untuk peningkatan Pendapatan Asli Daerah (PAD), pengusaha memiliki kepentingan keuntungan bisnis pengelolaan sumber daya alam, LSM sebagai sebuah kelompok penekan dalam pengawasan pengelolaan lingkungan dan khusus untuk masyarakat merupakan bagian terpenting karena hampir tak berjarak dengan lingkungan. Sebab, ketika bencana alam akibat kerusakan lingkungan terjadi, berdampak buruk pada seluruh kehidupan masyarakat, tidak peduli apakah masyarakat tersebut kaya atau miskin. Seluruhnya terkena bencana yang kemudian memiskinkan.

Kami melihat posisi perempuan nelayan ini sebagai sebuah fenomena baru yang tidak hanya dipandang sebagai sebuah pendamping saja. Lebih jauh, ketika melakukan wawancara dengan para perempuan nelayan di Desa Sei Nagalawan 
keinginan untuk diakui oleh negara menjadi hal penting. Sebab, peran yang sentral dalam melakukan reboisasi di Desa Sei Nagalawan kegiatan yang dilakukan oleh perempuan nelayan tidak hanya bertugas dalam kegiatan domestik layaknya pendamping saja. Seperti; memasak, mengurus anak, mengurus suami dan mempersiapkan kebutuhan untuk keluarga. Perempuan nelayan di Desa Sei Nagalawan juga terlibat dalam kegiatan sosial, ekonomi dan lebih terlibat juga dalam gerakan penyelamatan lingkungan di pesisir karena menginisiasi reboisasi mangrove untuk kebutuhan konservasi.

\section{SIMPULAN}

Pada akhir paper yang kami tulis ini, menjawab pertanyaan dasar mengenai bias sosial yang dihadapi oleh perempuan nelayan yang kami spesifikkan tidak hanya terjadi pada perempuan nelayan Desa Sei Nagalawan. Namun, lebih luas status sosial yang diskriminatif juga melekat pada perempuan nelayan, yang kerap hanya dianggap sebatas pendamping nelayan saja adalah sebuah sesat berpikir. Bukan tanpa alasan kami menyimpulkan demikian, itu merupakan sikap yang kami tulis. Sebab di narasi tulisan yang kami tulis ini sudah jelas menjawab bagaimana nyatanya perempuan nelayan mampu menggantikan peran-peran sosial nelayan laki-laki dalam keseharian mereka. Baik itu untuk bermasyarakat, menghadiri hajatan pernikahan atau melayan orang meninggal kerap digantikan oleh perempuan nelayan karena suami-suami mereka sedang melaut, beristirahat karena kecapean saat berlayar atau ikut-ikutan berfoya-foya dengan minum-minuman keras dan berjudi selepas melaut tanpa memperhatikan nasib keluarga.

Tidak hanya itu, beban kerja yang mencapai 18 jam perempuan nelayan. Sudah cukup menjadi jawaban tidak ada alasan lagi bagi pemerintah untuk tidak mengakui keberadaan perempuan nelayan dengan kebijakan nyata yang harus di ikat melalui undang-undang dan diimpelmentasikan dalam kebijakan yang berpihak pada nelayan. Lebih lanjut, kemiskinan struktural tidak akan mampu dilawan jika dilakukan secara individu. Modal sosial jika dimanfaatka dengan fondasi utama kepercayaan akan membawa situasi yang lebih baik lagi. Kelompok kelompok nelayan laki-laki Kayuh Baimbai tidak bisa maju tanpa kelompok perempuan nelayan Muara Tanjung di Desa Sei Ngalawan yang berujung pada terbentuknya Koperasi Serba Usaha (KSU) Muara Baimbai yang mengelola kawasan ekowisata Kampung Nipah. Artinya melihat keberhasilan kelompok nelayan di Desa Sei Nagalawan yang menjadikan perempuan nelayan tidak hanya sebagai pendamping saja. Tapi pada posisi fungsi sosial sudah terlihat sebagai bagian sendiri dengan posisi yang setara.

Paper yang kami tulis ini diakhiri dengan rekomendasi kebijakan yang menyangkut stakeholders (pemangku kepantingan) utama yaitu pemerintah pusat dan pemerintah daerah. Namun, lebih luas lagi rekomendasi kami juga terkait pemangku kepentingan lainnya seperti pengusaha, Lembaga Sosial Masyrakat (LSM), akademisi dan masyrakat. Sinergitas para pemangku kepentingan ini serasa sangat penting, terutama untuk kami staff pengajar di Fakultas Ilmu Budaya (FIB) dan Fakultas Ilmu Sosial dan Ilmu Politik (FISIP) sebagai sebuah rekomendasi naskah akademis yang kami harapkan bermanfaat pada perjuangan menuntut hak untuk perempuan nelayan. Lebih besar lagi, tulisan ini kami harapkan bisa menjadi sumbangan pikiran untuk pemerintah dalam mengatasi kemiskinan struktural yang ada di pesisir. 


\section{DAFTAR PUSTAKA}

Lentisco. A \& Lee, R.U (2015), A Review of Women's Access To Fish In Small-Scale Fisheries food and Agriculture Organization Of The United Nations Rome. FAO Fish eries and Aquaculture Circular No. 1098: 8-9.

Bird, K, (2013), The Political Representation of Women and Ethnic Minoritie in Established Democracies: A Frame work for Comparative Research, Working Paper presented for the Academy of Migration Studies in Denmark (AMID), Aalborg University

Bryant, R \& Bailey, S. (1997). Third World Political Ecology. London. Routlegde Press.

Denzin, N. K \& Lincon, Y.S (2009), Handbook of Qualitative Research, Yogyakarta : Pustaka pelajar.

Smith, D,E. (1987). The Everyday World ss Problematic: A Feminist Sociology. Northeastern University Press

Denzin \& Lincoln. (2009). Handbook of Qualitative Research. Yogyakarta: Pustaka Pelajar

Gaard, G, (1992), Ecofeminism Women, Animals, Nature, Philadelphi : Temple University Press.

Giddens, A. (2001), Introduction, in A. Giddens (ed.) The Global Third Way Debate, Cambridge: Polity Press, hal.1-24.

Hanson, (1997), How poverty lostit' smeaning, Cato Journal , hal.5-7.

Handoko, W, Marwah, S \& Ardhanariswari, R. (2013), Pembentukan Model Pemberdayaan
Perempuan Nelayan di Daerah Tertinggal, Fakultas Ilmu Sosial dan Ilmu Politik, Universitas Jenderal Soedirman, Purwokerto.

Khodijah, (2014), Sustainable Live lihoods of Fishermen House holds Headed by Women (Case Study in Riau Islands Province of Indonesia), Published by Canadian Center of Science and Education, Asian Social Science; 10 (9); 2014

Malau, W. (2014). Pengarusutamaan Gender dalam Program Pembangunan. Jurnal Pendidikan Ilmu-Ilmu Sosial, 6 (2): 125-131

Munthe. H.M, Hafi. B. (2018). Pemberdayaan Gender Pada Tokoh Adat untuk Mendukung Peran Perempuan dalam Pembangunan Desa. Journal of Education, Humaniora and Social Sciences (JEHSS). 1 (2): 60-65.

Satria, A. (2010), Ekologi Politik Nelayan, Yogyakarta : Lkis Printing Cemerlang.

Rogers, B, (1980), The Domestic of women, New York: Tavistock Publication.

Suardiman, S, P. (2001), perempuan kepala rumah tangga, Yogyakarta : Jendela.

Pand, V, V., Mohan, M \& Pradesh, A. (2015), Economic And Domestic Activities Of Maritime Fisher Women of North Coastal, Journal of Current. 7 (10) : 21082-21086.

Ware, H. (1981), Women, Demografhy, dan Development,Canberra. The Australian National University.

Shiva, V, (1993), Ecofeminism, London \& New Jersey: Zed Books. 